\title{
Fertigation and growth regulator on coffee seedling production in tubes ${ }^{1}$
}

\author{
Victor Peçanha de Miranda Coelho², Kelly Martins Rosa², \\ Paulo Eduardo Branco Paiva ${ }^{2}$, Édimo Fernando Alves Moreira² ${ }^{2}$ Mychelle Carvalho $^{2}$
}

\section{ABSTRACT}

The use of quality seedlings is important in establishing a productive coffee crop. However, the most widely used method to produce coffee seedlings is time consuming (6-12 months) and lacks new production technologies. This study aimed to assess the use of fertigation and a growth regulator in the production of coffee seedlings, in order to develop a system faster than the conventional method. For that, Topázio coffee cultivar seeds were pre-germinated and planted in tubes filled with substrate (composted pine bark), in a protected nursery. A randomized block design was used, in a $4 \times 2$ (fertigation levels $\mathrm{x}$ the use or not of growth regulator) factorial scheme, with four replications. Daily fertigation positively influenced all the growth variables evaluated. The foliar spraying of the growth regulator had little effect on seedling growth. When compared to the conventional system described in the literature, the coffee seedling production system described here reduced, by around 60 days, the production time and enables a largescale production.

KEYWORDS: Coffea arabica L.; electrical conductivity; substrate.

\section{INTRODUCTION}

Brazil produced 45.5 million bags of coffee in 2017, with exports totaling USD 2.5 billion dollars that year. The Minas Gerais state is the largest producer, with 25.7 million bags, corresponding to $56.5 \%$ of the national production (Agrianual 2018). The Brazilian Savannah region, particularly the Minas Gerais Triangle, stands out for its highgrade Arabica coffee production (Fernandes et al. 2012), and the use of quality seedlings is vital in establishing a productive crop, increasing the chances of successful coffee farming (Tomaz et al. 2015).

\section{RESUMO}

Fertirrigação e regulador de crescimento na produção de mudas de café em tubete

A utilização de mudas de boa qualidade é importante para a formação de uma lavoura produtiva de café. Entretanto, o método mais utilizado atualmente para a produção de mudas de cafeeiro é demorado (6-12 meses) e carece de novas tecnologias de produção. Objetivou-se avaliar a utilização de fertirrigação e regulador de crescimento na produção de mudas de cafeeiro, com vistas ao desenvolvimento de um sistema mais rápido que o sistema convencional de produção. Para isso, sementes da cultivar Topázio foram pré-germinadas e plantadas em tubetes com substrato (casca de pinus compostada), em viveiro coberto. Adotou-se o delineamento de blocos ao acaso, em esquema fatorial 4 × 2 (níveis de fertirrigação x utilização ou não de regulador de crescimento), com quatro repetições. A fertirrigação diária influenciou positivamente em todas as variáveis de crescimento analisadas. A pulverização foliar do regulador de crescimento apresentou pouco efeito sobre o crescimento das mudas. Quando comparado ao sistema convencional descrito na literatura, o sistema de produção de mudas de cafeeiro descrito neste trabalho reduziu, em cerca de 60 dias, o tempo de produção e permite a produção em larga escala.

PALAVRAS-CHAVE: Coffea arabica L.; condutividade elétrica; substrato.

There are many systems for producing coffee seedlings, either using plastic bags or tubes, with different substrates and organic, conventional or slow-release fertilizers (Vallone et al. 2010). In the commercial seedling production, most producers and nurseries use plastic bags containing a mixture of cattle manure and subsurface soil as substrate, supplemented with chemical fertilizers (Tomaz et al. 2015). However, this method is time consuming (at least six months), requires significant manpower and involves the risk of contamination by pathogens, making it inefficient.

In recent decades, there has been a growing number of initiatives aimed at improving and

1. Received: Mar. 27, 2018. Accepted: Jul. 19, 2018. Published: Oct. 10, 2018. DOI: 10.1590/1983-40632018v4852148.

2. Instituto Federal de Educação, Ciência e Tecnologia do Triângulo Mineiro, Uberaba, MG, Brasil. E-mail/ORCID: victorcoelho@iftm.edu.br/0000-0003-0024-3304, kellymartinsrosap@gmail.com/0000-0002-0668-3514,paulopaiva@iftm.edu.br/ 0000-0002-9859-4251, edimo@iftm.edu.br/0000-0003-2659-5033,mychellecarvalho@iftm.edu.br/0000-0001-8945-1550. 
shortening the coffee seedling production process. These include the use of seed germination techniques (Meireles et al. 2007, Lima et al. 2012), tubes and quality substrates, different fertilization practices (Müller et al. 1997, Ferreira 2014, Tomaz et al. 2015), biostimulants and growth regulators (Guimarães 1995, Melo \& Maciel 2014).

Rigid polyethylene tubes have increasingly been used in coffee seedling production, because they reduce the chances of contamination by pathogens; increase direct root growth and mitigate $\mathrm{J}$ root problems (bent taproot); stimulate the growth of side roots; require less substrate; and decrease the incidence of weeds, space needed in the nursery and transportation costs (Tomaz et al. 2015).

The most widely used substrates in tube-based production are those containing composted pine bark, because they are inexpensive and exhibit adequate porosity and water retention capacity (Zorzeto et al. 2014). However, they require a continuous application of fertilizers. Slow-release fertilizers are favored, but the release of nutrients depends on temperature (Adams et al. 2013), a non-controllable factor. Another alternative is to apply mineral and organic fertilizers to the substrate before planting (Dias et al. 2009); however, homogeneity must be guaranteed and nutrient leaching occurs after irrigation, particularly anions such as nitrates and sulfates.

Fertigation has been employed in the production of citrus seedlings (Bataglia et al. 2008), but is still little used by coffee seedling producers. Fertigation allows nutrients to be administered in a controlled manner and at regular time intervals, preventing problems related to heterogeneous availability and reducing nutrient loss through leaching.

The use of biostimulants or growth regulators can increase the plant growth and development by stimulating cell division, differentiation and cell elongation, in addition to improving the absorption and use of nutrients (Castro et al. 1998, Pasala et al. 2016, Yakhin et al. 2017). Stimulate ${ }^{\circledR}\left(\right.$ Stoller $\left.^{\circledR}\right)$, a growth regulator from the cytokinin $\left(90 \mathrm{mg} \mathrm{L}^{-1}\right)+$ auxin $\left(50 \mathrm{mg} \mathrm{L}^{-1}\right)+$ gibberellin $\left(50 \mathrm{mg} \mathrm{L}^{-1}\right)$ chemical group, is used to promote higher yields and rooting rates (Castro et al. 1998). This biostimulant is recommended by the manufacturer for coffee, cotton, rice, bean, sugarcane, maize, soybean, lettuce, tomato, barley, wheat, citrus and grape crops.

Despite the existence of pre-germination techniques and research on fertigation and growth regulators in seedling production, there is still insufficient consolidated information on the adoption of these techniques for coffee seedlings, what may explain their scant use by nurseries. As such, this study aimed to assess the use of fertigation and a growth regulator in the production of coffee seedlings, in order to develop a system faster than the conventional method.

\section{MATERIAL AND METHODS}

Fruits of the Topázio coffee cultivar were collected in the 2016 growing season from a coffee plantation of the Instituto Federal de Educação, Ciência e Tecnologia do Triângulo Mineiro, in Uberaba, Minas Gerais state, Brazil, where the experiment was conducted. To obtain the seeds, the fruits were peeled and demucilaged in accordance with Tomaz et al. (2015). The seeds were germinated using the Secafé method (Meireles et al. 2007), which consists of chemical pretreatment with $5 \%$ sodium hypochloride for $6 \mathrm{~h}$ to remove the endocarp, water imbibing for $12 \mathrm{~h}$ and incubation in a seed incubator at $28^{\circ} \mathrm{C}$. After 10 days in the incubator, seeds with a radicle of up to $4 \mathrm{~mm}$ long were selected and planted in cone-shaped tubes $(120 \mathrm{~mm} \times 30 \mathrm{~mm}$, with a volume of $50 \mathrm{~cm}^{3}$ ) filled with Bioplant Ouro substrate $\left(\right.$ Bioplant $\left.^{\circledR}\right)$ and irrigated daily.

The experiment was conducted from October 2016 to February 2017, in a nursery covered with $50 \%$ shade cloth and plastic film. A randomized block design, in a $4 \times 2$ factorial scheme, with four replications, was used. The first factor consisted of four fertigation levels, encompassing fertilizer concentrations, electrical conductivity of the nutrient solution and their respective $\mathrm{pH}$ values (Table 1).

Table 1. Electrical conductivity $\left(\mathrm{dS} \mathrm{m}^{-1}\right)$, fertilizer concentration $\left(\mathrm{g} \mathrm{m}^{-3}\right.$ of water) and $\mathrm{pH}$ of the nutrient solutions used to fertigate coffee seedlings.

\begin{tabular}{lcrrr}
\hline \multirow{2}{*}{ Fertilizer } & \multicolumn{5}{c}{ Electrical conductivity $\left(\mathrm{dS} \mathrm{m}^{-1}\right)^{1,2}$} \\
\cline { 2 - 5 } & 0.0 & 1.0 & 2.0 & \multicolumn{1}{c}{3.0} \\
\hline Calcium nitrate & 0 & 400 & 800 & 1,200 \\
Potassium nitrate & 0 & 250 & 500 & 750 \\
Magnesium sulphate & 0 & 175 & 350 & 525 \\
Ammonium monophosphate & 0 & 50 & 100 & 150 \\
ConMicros $^{\circledR 3}$ & 0 & 25 & 25 & 25 \\
\hline $\mathrm{pH}^{4}$ & 6.9 & 6.7 & 6.5 & 6.2 \\
\hline
\end{tabular}

${ }^{1}$ Measured using a handheld conductivity meter (CD-203, Phtek); ${ }^{2}$ values based on Furlani (1999); ${ }^{3}$ ConMicros Standard ${ }^{\mathbb{B}}$ - micronutrient mixture (Allplant ${ }^{\mathbb{\mathbb { R }}}$ ); ${ }^{4}$ measured with a portable $\mathrm{pH}$ meter (PH-100, Phtek). 
The second factor involved the use or not of the leaf-applied growth regulator Stimulate ${ }^{\circledR}$, at the concentration recommended by the manufacturer for coffee plants $\left(0.5 \mathrm{~mL} \mathrm{~L}^{-1}\right)$.

Each experimental unit consisted of four rows containing three tubes each, forming a rectangle of 12 seedlings. The four plants in the center rows were used as the study plot. The tubes were placed in plastic trays on a 1.0-m-high bench. At ten days after the seeds were planted in tubes ('matchstick' stage), the substrate was irrigated (treatment $0.0 \mathrm{dS} \mathrm{m}^{-1}$ ) or fertigated (treatments $1.0 \mathrm{dS} \mathrm{m}^{-1}, 2.0 \mathrm{dS} \mathrm{m}^{-1}$ and $3.0 \mathrm{dS} \mathrm{m}^{-1}$ ) daily, using a plastic wash bottle. Water or nutrient solution $\left(80-100 \mathrm{~mL} \mathrm{plot}^{-1}\right)$ was applied until one of the tubes started driping from its bottom. Stimulate ${ }^{\circledR}$ was sprayed every 14 days, using a 1-L handheld sprayer $\left(\right.$ Worker $\left.^{\circledR}\right)$, starting one month after planting in tubes (when the first pair of leaves began to open). A bulkhead was used to isolate the plot being sprayed from the others, to prevent spray drifting.

The seedlings were assessed at 120 days after the tube planting (DAP), when they exhibited 3-4 pairs of leaves, which is the period recommended for field planting. Shoot and root fresh mass (g), shoot and root dry mass $(\mathrm{g})$, shoot and root length $(\mathrm{cm})$ and shoot to root ratio were evaluated and leaf area $\left(\mathrm{cm}^{2}\right)$ was measured using the Image $\mathrm{J}^{\circledR}$ software. Analysis of variance and regression were performed with the R software (R Core Team 2016). The plants were photographed every month from the seed stage up to 120 DAP, in order to describe and characterize the chronological sequence of the seedling production process in all development stages.

\section{RESULTS AND DISCUSSION}

The seeds germinated at 7 days after sowing, at a rate of $90 \%$ (Figure $1 \mathrm{~A}$ ). The seedlings emerged at $10 \mathrm{DAP}$, reaching the so-called 'matchstick' stage.
The cotyledonary leaves (referred to as 'panther ears' by Brazilian growers) opened at 22 DAP(Figure 1B). Leaf pairs emerged in the following chronological order: first pair at 45 DAP (Figure 1C); second pair at 60-80 DAP (Figure1D); third pair at 90-100 DAP; and fourth pair at $120 \mathrm{DAP}$ (Figure 1E).

At 120 DAP, the roots were well developed, with several side roots that occupied almost the entire tube volume (Figure 1F). The plants submitted to fertigation showed no obvious visual differences, whereas those treated without fertilizers $\left(0.0 \mathrm{dS} \mathrm{m}^{-1}\right)$ exhibited a delayed development and shoot yellowing (Figure 1E).

There was no significant interaction between the electrical conductivity and growth regulator factors for most of the variables, except for shoot length (Table 2). As such, the factors were studied separately, and interaction decomposition was performed only for the variable shoot length (Figure 2; Table 4).

The estimated maximum electrical conductivity values for the variables shoot fresh mass (2.2), root fresh mass (1.5), shoot dry mass (2.0), root dry mass (1.6) and leaf area (2.1) were obtained in the 1.4-2.2 $\mathrm{dS} \mathrm{m}^{-1}$ range. The maximum root length was estimated at $0.9 \mathrm{dS} \mathrm{m}^{-1}$. At this electrical conductivity range, which promotes the highest plant growth, the shoot to root ratio values were estimated between 5.5 and 7.0 (Figure 2). With respect to the growth regulator, a significant difference was only observed for root length, whereby the treated seedlings showed less root growth (Tables 2 and 3).

The maximum shoot length was obtained at a conductivity of approximately $2.0 \mathrm{dS} \mathrm{m}^{-1}$, with or without foliar spraying of the growth regulator. The growth regulator effect analysis for each fertigation level indicated a significant difference for shoot length only at $0.0 \mathrm{dS} \mathrm{m}^{-1}$, when the treated seedlings exhibited less growth (Table 4).

Table 2. Analysis of variance (F test) for the variables shoot length (SL), root length (RL), shoot fresh mass (SFM), root fresh mass (RFM), shoot dry mass (SDM), root dry mass (RDM), leaf area (LA) and shoot to root ratio (SRR), at 120 days after planting.

\begin{tabular}{lccccccccc}
\hline \multirow{2}{*}{ Source of variation } & \multirow{2}{*}{ DF } & \multicolumn{1}{c}{ F } \\
\cline { 3 - 10 } & & SL & RL & SFM & RFM & SDM & RDM & LA & SRR \\
\hline Blocks & 3 & $2.08^{\text {ns }}$ & $0.25^{\text {ns }}$ & $0.76^{\text {ns }}$ & $1.86^{\text {ns }}$ & $0.34^{\text {ns }}$ & $0.06^{\text {ns }}$ & $1.65^{\text {ns }}$ & $0.62^{\text {ns }}$ \\
Electrical conductivity & 3 & $490.70^{* *}$ & $8.46^{* *}$ & $118.55^{* *}$ & $61.18^{* *}$ & $221.51^{* *}$ & $26.91^{* *}$ & $169.74^{* *}$ & $344.93^{* *}$ \\
Growth regulator & 1 & $1.49^{\text {ns }}$ & $4.458^{*}$ & $0.03^{\text {ns }}$ & $0.23^{\text {ns }}$ & $2.57^{\text {ns }}$ & $1.07^{\text {ns }}$ & $3.61^{\text {ns }}$ & $0.50^{\text {ns }}$ \\
Interaction & 3 & $3.15^{*}$ & $0.59^{\text {ns }}$ & $0.47^{\text {ns }}$ & $1.21^{\text {ns }}$ & $0.79^{\text {ns }}$ & $0.23^{\text {ns }}$ & $1.01^{\text {ns }}$ & $0.48^{\text {ns }}$ \\
\hline CV\% & - & 4.21 & 6.85 & 11.71 & 11.58 & 10.12 & 15.72 & 9.58 & 7.41 \\
\hline
\end{tabular}

ns non-significant; * significant at $5 \%$ of probability; ** significant at $1 \%$ of probability. 

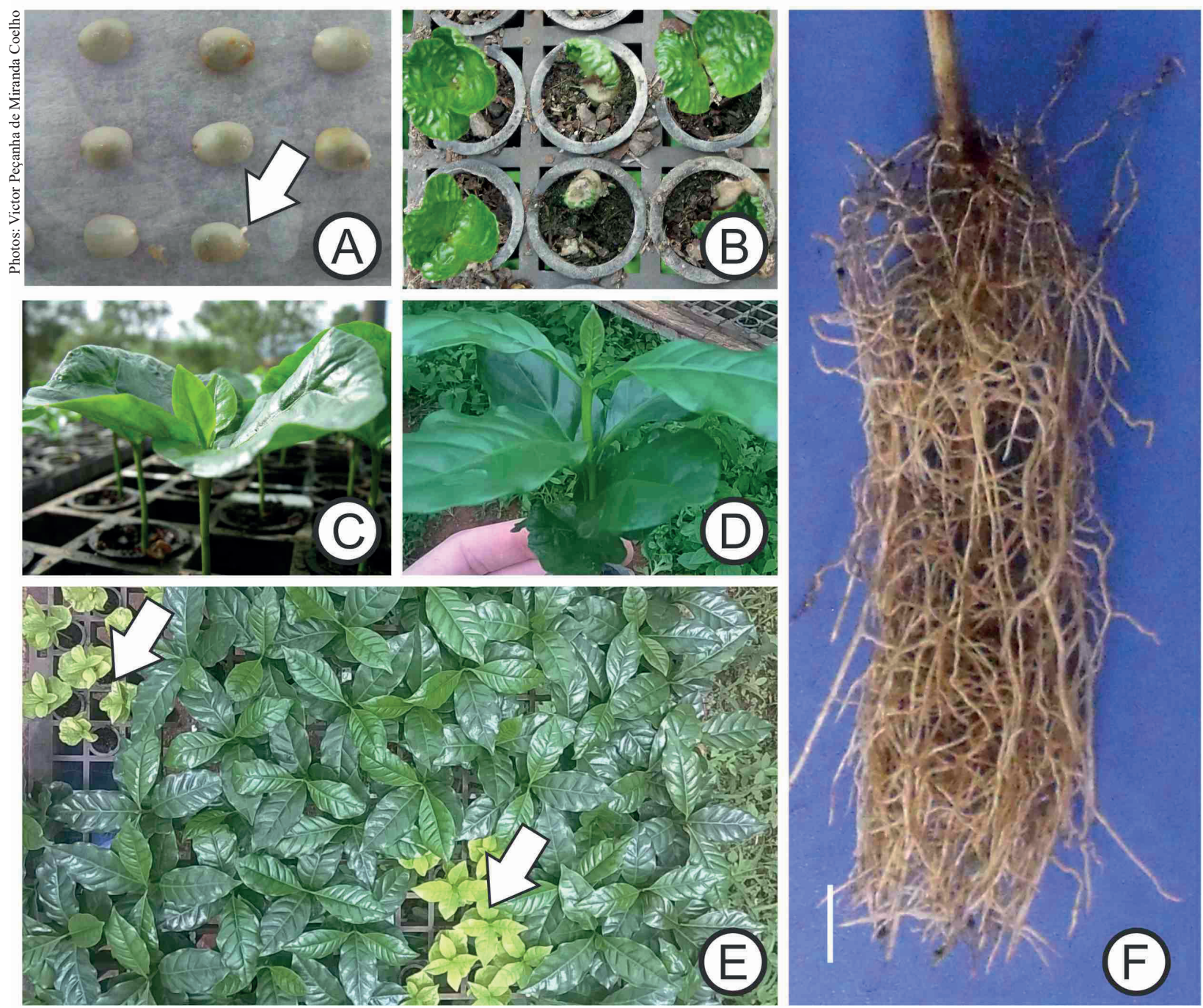

Figure 1. A-G) Timeline for coffee seedling production from germination up to 120 days after planting (DAP); A) germinated seeds (arrow); B) plants in the 'matchstick' and 'panther ears' stages, approximately at 10-20 DAP; C) plants with 1 leaf pair at 45 DAP; D) plants with 2 well-developed leaf pairs at 80 DAP; E) plants with 3 or 4 leaf pairs at 120 DAP, with arrows indicating seedlings without fertilizer $\left.\left(0.0 \mathrm{dS} \mathrm{m}^{-1}\right) ; \mathrm{F}\right)$ roots at $120 \mathrm{DAP}\left(1.0 \mathrm{dS} \mathrm{m}^{-1}\right)$, with $\mathrm{bar}=1 \mathrm{~cm}$.

Table 3. Growth variables of coffee seedlings at 120 days of planting, with and without growth regulator application.

\begin{tabular}{lcc}
\hline \multirow{2}{*}{ Variable } & \multicolumn{2}{c}{ Means } \\
\cline { 2 - 3 } & $\begin{array}{c}\text { With growth } \\
\text { regulator }\end{array}$ & $\begin{array}{c}\text { Without growth } \\
\text { regulator }\end{array}$ \\
\hline Shoot length $(\mathrm{cm})$ & $*$ & $*$ \\
Root length $(\mathrm{cm})$ & $11.73 \pm 0.2026 \mathrm{~b}$ & $12.35 \pm 0.3127 \mathrm{a}$ \\
Shoot fresh mass $(\mathrm{g})$ & $2.80 \pm 0.3048 \mathrm{a}$ & $2.82 \pm 0.2807 \mathrm{a}$ \\
Root fresh mass $(\mathrm{g})$ & $1.32 \pm 0.1062 \mathrm{a}$ & $1.29 \pm 0.0964 \mathrm{a}$ \\
Shoot dry mass $(\mathrm{g})$ & $1.08 \pm 0.1338 \mathrm{a}$ & $1.02 \pm 0.1209 \mathrm{a}$ \\
Root dry mass $(\mathrm{g})$ & $0.18 \pm 0.0133 \mathrm{a}$ & $0.17 \pm 0.0126 \mathrm{a}$ \\
Leaf area $\left(\mathrm{cm}^{2}\right)$ & $205.60 \pm 20.75 \mathrm{a}$ & $192.78 \pm 19.64 \mathrm{a}$ \\
Shoot to root ratio & $5.61 \pm 0.6378 \mathrm{a}$ & $5.71 \pm 0.6091 \mathrm{a}$ \\
\hline * The fertigation and growth regulator interaction was significant. Means followed \\
by the same letter in the row do not differ according to the F test.
\end{tabular}

In order to be deemed suitable for field planting, a coffee seedling should exhibit 3-5 leaf pairs and shoot to root balance (Tomaz et al. 2015). In this study, the biometric data demonstrated a

Table 4. Effect of growth regulator on the shoot length variable, at four fertigation levels and 120 days of planting.

\begin{tabular}{ccc}
\hline Fertigation & With growth regulator & Without growth regulator \\
\hline 0 & $9.61 \pm 0.5659 \mathrm{~b}$ & $11.33 \pm 0.5495 \mathrm{a}$ \\
1 & $24.78 \pm 0.4984 \mathrm{a}$ & $24.22 \pm 0.1945 \mathrm{a}$ \\
2 & $24.09 \pm 0.3746 \mathrm{a}$ & $24.89 \pm 0.7455 \mathrm{a}$ \\
3 & $23.21 \pm 0.3217 \mathrm{a}$ & $22.76 \pm 0.0484 \mathrm{a}$ \\
\hline
\end{tabular}

Means \pm standard error followed by the same letter in the rows do not differ according to the $\mathrm{F}$ test. 

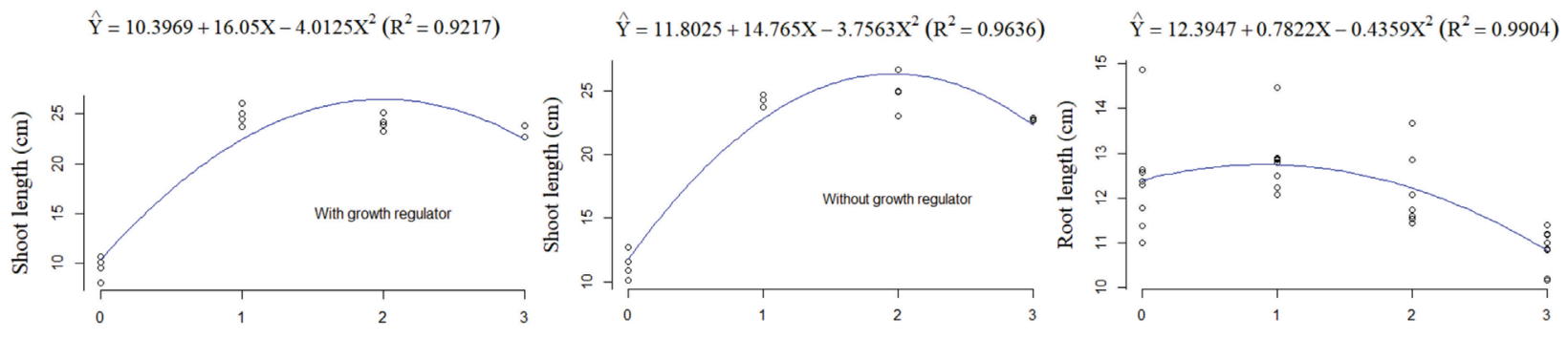

$\hat{\mathrm{Y}}=1.0159+2.6014 \mathrm{X}-0.6018 \mathrm{X}^{2}\left(\mathrm{R}^{2}=0.9585\right)$

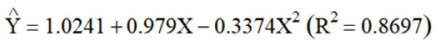

$\hat{\mathrm{Y}}=0.2672+1.272 \mathrm{X}-0.3212 \mathrm{X}^{2}\left(\mathrm{R}^{2}=0.9447\right)$
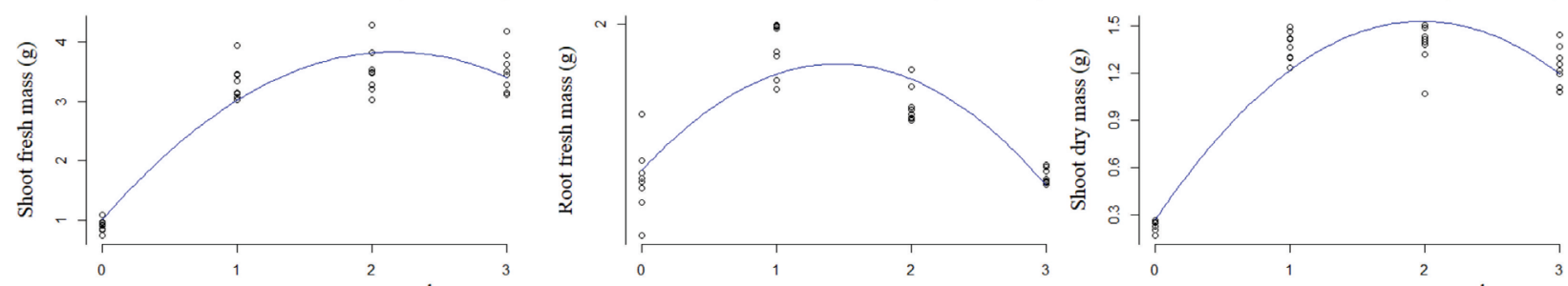

$\hat{\mathrm{Y}}=0.1271+0.1332 \mathrm{X}-0.0424 \mathrm{X}^{2}\left(\mathrm{R}^{2}=0.9299\right)$
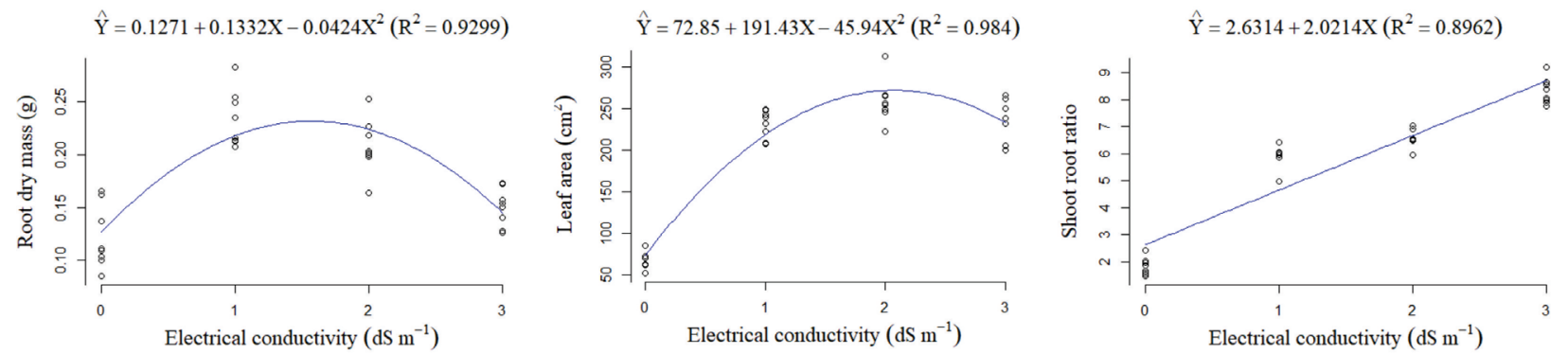

Figure 2. Regression adjustments for the variables: shoot length (with and without growth regulator); root length (cm); shoot and root fresh mass $(\mathrm{g})$; shoot and root dry mass $(\mathrm{g})$; leaf area $\left(\mathrm{cm}^{2}\right)$; and shoot to root ratio, as a function of fertigation in coffee seedlings, at 120 days after planting.

good plant development at 120 DAP. The growth parameters used were similar to those reported by Marana et al. (2008) and Der Vliet et al. (2009) for 150-day-old coffee seedlings and by Melo \& Maciel (2014) at 189 DAP.

The beneficial effect of the higher electrical conductivity of the nutrient solution on growth is likely due to the greater supply of nutrients to the plants, since electrical conductivity was raised by increasing the fertilizer concentration in the nutrient solution. However, except for the shoot to root ratio, a decline was observed in the variables from a certain electrical conductivity (i.e., approximately $2.0 \mathrm{dS} \mathrm{m}^{-1}, 1.5 \mathrm{dS} \mathrm{m}^{-1}$ and $1.0 \mathrm{dS} \mathrm{m}^{-1}$, respectively for shoot-related variables, root fresh and dry mass and root length) (Figure 2). This is believed to be linked to the osmotic effect. High salt levels in the nutrient solution reduce its osmotic and water potential, making it more difficult for the roots to absorb water and nutrients. Under these conditions, energy is transferred for the purpose of osmotic adjustment, what may compromise certain physiological processes and reduce plant growth (Brady \& Weil 2013, Taiz et al. 2017). This effect is more evident and worrisome in plants in the early stages of development (Brady \& Weil 2013) and in systems where minimum drainage is adopted (Beckmann-Cavalcante et al. 2010), as occurred in the present study. Furthermore, it is important to note that, although the $\mathrm{pH}$ solution varied as a function of electrical conductivity (Table 1), the values were within the appropriate range for nutrient solutions.

The solution with the highest electrical conductivity $\left(3.0 \mathrm{dS} \mathrm{m}^{-1}\right)$ was harmful to the plants, reducing the root growth and increasing the shoot to root ratio. As such, the electrical conductivity and $\mathrm{pH}$ of the nutrient solutions used in fertigation should be monitored regularly. In the present study, this was achieved using portable easy-to-use devices. Thus, the poor fertigation infrastructure for coffee seedlings observed by Marana et al. (2008) in nurseries should 
not be an obstacle, since the necessary equipment is inexpensive and easy to use.

In a pursuit of alternatives to shorten the production time of coffee seedlings, Guimarães (1995) removed the endocarp and used exogenous cytokinin to germinate coffee seeds, in addition to applying $\mathrm{N}$ and $\mathrm{K}$ for seedlings cultivated in a nursery. However, none of the treatments adopted reduced the production time.

The production process presented here includes endocarp removal and seed germination at around 10 days, plus 120 days of cultivation in a nursery, totaling 130 days to produce a coffee seedling with desirable traits for transplantation to the field. This is 60 days less than the conventional production process described in the literature (Tomaz et al. 2015). Moreover, seed (only one is planted per tube) and manpower expenditures are also lower, since there is no need for the selection and thinning required under the conventional system.

A balanced fertilization is essential during the production process to obtain vigorous seedlings. Although the commercial substrates available for growing coffee seedlings in tubes contain fertilizers, they do not guarantee an adequate nutrient availability. Thus, an alternative to adding fertilizer throughout the production process is the use of slowrelease fertilizers (Tomaz et al. 2015). However, the release of nutrients depends on soil moisture and temperature and cannot be controlled (Adams et al. 2013). Additionally, Boaventura et al. (2004) report that slow-release fertilizers are more likely to cause soil acidification and salt stress.

The nutritional management using nutrient solutions and controlling electrical conductivity and $\mathrm{pH}$ has been applied in the production of citrus (Bataglia et al. 2008), potato (Calori et al. 2017), lettuce (Helbel Junior et al. 2008) and flower (Ludwig \& Fernandes 2013) seedlings. The benefits of this technique are a better fertilizer distribution in the container and the ability to increase the number of fertilizer applications, improving the nutrient absorption by plants (Duenhas et al. 2005). For citrus seedlings, fertilization via fertigation was found to be more efficient than slow-release fertilizers at providing the recommended amount of nutrients (Boaventura 2003). Fertigation is a technical and economically viable process commonly used for coffee crops (Fernandes et al. 2007), but it has yet to be studied for the production of coffee seedlings.
Larger containers may result in larger seedlings (Vallone et al. 2010), but require more space and investment, when composted pine bark or coconut fiber substrates are used. Small containers, such as cylindrical $50 \mathrm{~cm}^{3}$ tubes, are easy to handle and require less space, substrate and fertilizer. Thus, the knowledge of the best nutritional management strategy will ensure economic gains and quality seedlings. Another advantage of growing coffee seedlings in smaller containers $\left(50 \mathrm{~cm}^{3}\right.$ or $\left.120 \mathrm{~cm}^{3}\right)$ is a greater plant adherence to the substrate, which does not break up during planting (Favarin et al. 2008). However, when comparing the root data obtained here in $50 \mathrm{~cm}^{3}$ tubes (root length $=12.7 \mathrm{~cm}$; root dry mass $=0.23 \mathrm{~g}$ ) with those reported by Marana et al. (2008) in $120 \mathrm{~cm}^{3}$ tubes (root dry mass $=0.24 \mathrm{~g}$ ) and data from studies that used larger containers, such as $180 \mathrm{~mL}$ tubes (Der Vliet et al. 2009; root dry mass $=0.72 \mathrm{~g}$ ) and $18 \mathrm{~cm} \mathrm{x} 4 \mathrm{~cm}$ bags (Melo \& Maciel 2014; root length $=18.9 \mathrm{~cm}$; root dry mass $=$ $0.74 \mathrm{~g}$ ), it can be inferred that smaller containers may restrict root growth.

The use of growth regulators (Pasala et al. 2016) or biostimulants (Yakhin et al. 2017) has attracted the attention of researchers and agricultural companies. Nevertheless, results for the production of coffee seedlings are scarce and controversial. In seedlings with 3-4 or up to 8 leaf pairs (pruned at pair 4), subsequently transplanted to 20 -L pots and assessed at 180 days after transplantation, Stimulate ${ }^{\circledR}$ (growth regulator) promoted plant growth, particularly at a dose of $0.1 \%$ (Silva et al. 2013). In seedlings deemed too old (18 months), after 10 months of cultivation in a nursery, Stimulate ${ }^{\circledR}$ increased the stem diameter only in the treatment with burned coffee husk substrate (Ferreira et al. 2015). On the other hand, Stimulate ${ }^{\circledR}$ associated with thiamethoxam and triadimenol did not favor the coffee seedling growth up to 189 DAP (Melo \& Maciel 2014). Stimulate ${ }^{\circledR}$ applied to seeds $\left(10 \mathrm{~mL} \mathrm{~kg}^{-1}\right)$ also failed to promote growth in coffee seedlings evaluated at 150 DAP (Der Vliet et al. 2009). These findings corroborate those obtained here, whereby Stimulate ${ }^{\circledR}$ showed no positive or negative effect on the growth variables.

Although different plant species, cultivars and phenological stages have different nutritional needs (Ludwig \& Fernandes 2013), and despite the difficulties involved in applying fertilizers or fertigation to tubes (Marana et al. 2008, Tomaz et al. 2015), this study may contribute to the adoption 
of fertigation in coffee seedling production. On the other hand, in the light of our results and based on the literature, Stimulate ${ }^{\circledR}$ has little or no effect on coffee seedlings (up to 6 months after planting), but increases growth slightly in larger seedlings that are too old for transplantation.

The process presented in this study reduced the production time of Arabica coffee seedlings by $\sim 60$ days. The resulting seedlings exhibited traits consistent with those described in the literature for quality seedlings ready for transplantation. The process described here shows potential for large-scale use, but more knowledge is needed, regarding factors such as the effect of different growth regulator concentrations, use of different containers, the best fertigation regime and the field establishment of seedlings.

\section{CONCLUSIONS}

Daily fertigation using nutrient solutions with electrical conductivities of 1.4-2.2 $\mathrm{dS} \mathrm{m}^{-1}$ are efficient in the production of coffee seedlings. The biweekly foliar spraying of the growth regulator had no effect on seedling growth. As such, under these conditions, its use is not recommend in the production of coffee seedlings up to 120 days after planting.

\section{ACKNOWLEDGMENTS}

The authors are grateful to the Fundação de Amparo à Pesquisa do Estado de Minas Gerais (Fapemig), for supporting the Professional Master's Degree in Plant Production; the Instituto Federal de Educação, Ciência e Tecnologia do Triângulo Mineiro, for institutional support; and Professor Valdeci Orioli Júnior, for helping us with the discussion of the results.

\section{REFERENCES}

ADAMS, C. et al. Macro and micronutrient release characteristics of three polymer-coated fertilizers: theory and measurements. Journal of Plant Nutrition and Soil Science, v. 176, n. 1, p. 76-88, 2013.

AGRIANUAL: anuário da agricultura brasileira. 23. ed. São Paulo: FNP Consultoria e Comércio, 2018.

BATAGLIA, O. C. et al. Padrão nutricional de mudas de citros. Araraquara: Vivecitrus/Complant, 2008.

BECKMANN-CAVALCANTE, M. Z. et al. Condutividade elétrica da solução nutritiva para o cultivo do crisântemo em vaso. Revista Brasileira de Ciência do Solo, v. 34, n. 3, p. 747-756, 2010.

BOAVENTURA, P. S. R. Demanda de nutrientes de porta enxertos e mudas citricas produzidas em substrato em ambiente protegido. 2003. 62 f. Dissertação (Mestrado em Agricultura Tropical e Subtropical) - Instituto Agronômico de Campinas, Campinas, 2003.

BOAVENTURA, P. S. R. et al. Balanço de nutrientes na produção de mudas cítricas cultivadas em substrato. Revista Brasileira de Fruticultura, v. 26, n. 2, p. 300305, 2004.

BRADY, N. C.; WEIL, R. R. (Eds.). Elementos da natureza e propriedades dos solos. Porto Alegre: Bookman, 2013.

CALORI, A. H. et al. Electrical conductivity of the nutrient solution and plant density in aeroponic production of seed potato under tropical conditions (winter/spring). Bragantia, v. 76, n. 1, p. 23-32, 2017.

CASTRO, P. R. C. et al. Efeitos de stimulate e de microcitros no desenvolvimento vegetativo e na produtividade da laranjeira Pêra (Citrus sinensis L. Osbeck). Scientia Agricola, v. 55, n. 2, p. 338-341, 1998.

DER VLIET, W. H. V. et al. Enraizadores na formação de mudas de café em tubetes. In: CONGRESSO BRASILEIRO DE PESQUISAS CAFEEIRAS, 35., 2009, Araxá. Anais... Brasília, DF: Embrapa Café, 2009. 1 CD-ROM.

DIAS, R. et al. Fontes e proporção de material orgânico para a produção de mudas de cafeeiro em tubetes. Ciência e Agrotecnologia, v. 33, n. 3, p. 758-764, 2009.

DUENHAS, L. H. et al. Produção, qualidade dos frutos e estado nutricional da laranja Valência sob fertirrigação e adubação convencional. Engenharia Agrícola, v. 25, n. 1, p. 154-160, 2005.

FAVARIN, J. L. et al. Metodologia para estimar a estabilidade do conjunto muda $\mathrm{x}$ substrato de cafeeiro. Ciência Rural, v. 38, n. 1, p. 34-38, 2008.

FERNANDES, A. L. T. et al. Avaliação do uso de fertilizantes organominerais e químicos na fertirrigação do cafeeiro irrigado por gotejamento. Revista Brasileira de Engenharia Agrícola e Ambiental, v. 11, n. 2, p. 159166, 2007.

FERNANDES, A. L. T. et al. A moderna cafeicultura dos Cerrados brasileiros. Pesquisa Agropecuária Tropical, v. 42, n. 2, p. 231-240, 2012.

FERREIRA, A. D. et al. Crescimento de cafeeiros enxertados cultivados em solução nutritiva. Coffee Science, v. 9, n. 3, p. 312-318, 2014.

FERREIRA, R. O. et al. Aplicação de complexo hormonal no desenvolvimento de mudas do cafeeiro. 
In: CONGRESSO BRASILEIRO DE PESQUISAS CAFEEIRAS, 41., 2015, Poços de Caldas. Anais... Brasília, DF: Embrapa Café, 2015. 1 CD-ROM.

FURLANI, P. R. Soluções nutritivas. O Agronômico, v. 51, n. 1, p. 24-25, 1999.

GUIMARÃES, R. J. Formação de mudas de cafeeiro (Coffea arabica L.): efeitos de reguladores de crescimento e remoção do pergaminho na germinação de sementes e uso de $\mathrm{N}$ e $\mathrm{K}$ em cobertura, no desenvolvimento de mudas. 1995. 133 f. Tese (Doutorado em Agronomia) Universidade Federal de Lavras, Lavras, 1995.

HELBEL JUNIOR, C. et al. Influência da condutividade elétrica, concentração iônica e vazão de soluções nutritivas na produção de alface hidropônica. Ciência e Agrotecnologia, v. 32, n. 4, p. 1142-1147, 2008.

LIMA, J. S. et al. Uso da reidratação e do hipoclorito de sódio para acelerar a emergência de plântulas de cafeeiro. Revista Brasileira de Sementes, v. 34, n. 2, p. 327-333, 2012.

LUDWIG, F.; FERNANDES, D. M. Electrical conductivity and $\mathrm{pH}$ of the substrate solution in gerbera cultivars under fertigation. Horticultura Brasileira, v. 31, n. 3, p. 356360, 2013.

MARANA, J. P. et al. Índices de qualidade e crescimento de mudas de café produzidas em tubetes. Ciência Rural, v. 38, n. 1, p. 39-45, 2008.

MEIRELES, R. C. et al. Secafé: metodologia para acelerar a germinação das sementes de café. Revista Brasileira de Sementes, v. 29, n. 3, p. 90-96, 2007.

MELO, B. M. R.; MACIEL, A. L. R. Influência de bioativadores e bioestimulantes na produção de mudas de cafeeiros. Revista Agrogeoambiental, v. 6, n. 3, p. 5562, 2014.

MÜLLER, M. M. L. et al. Produção de mudas de cafeeiro (Coffea arabica L.) cv. Mundo Novo em tubetes. Revista Unimar, v. 19, n. 3, p. 777-786, 1997.

PASALA, R. K. et al. Can plant bio-regulators minimize crop productivity losses caused by drought, heat and salinity stress?: an integrated review. Journal of Applied Botany and Food Quality, v. 89, n. 1, p. 113-125, 2016.

R CORE TEAM. $R$ : a language and environment for statistical computing. Vienna: R Foundation for Statistical Computing, 2016.

SILVA, V. A. et al. Avaliação do efeito do Stimulate ${ }^{\circledR}$ sobre mudas de café em dois modos de aplicação. In: CONGRESSO BRASILEIRO DE PESQUISAS CAFEEIRAS, 39., 2013, Poços de Caldas. Anais... Brasília, DF: Embrapa Café, 2013. 1 CD-ROM.

TAIZ, L. et al. Fisiologia e desenvolvimento vegetal. 6. ed. Porto Alegre: Artmed, 2017.

TOMAZ, M. A. et al. Produção de mudas e plantio. In: SAKIYAMA, N. S. et al. Café arábica: do plantio à colheita. Viçosa: Ed. UFV, 2015. p. 46-63.

VALLONE, H. S. et al. Diferentes recipientes e substratos na produção de mudas de cafeeiros. Ciência e Agrotecnologia, v. 34, n. 1, p. 55-60, 2010.

YAKHIN, O. I. et al. Biostimulants in plant science: a global perspective. Frontiers in Plant Science, v. 7, n. 1, p. 1-32, 2017.

ZORZETO, T. Q. et al. Caracterização física de substratos para plantas. Bragantia, v. 73, n. 3, p. 300-311, 2014. 